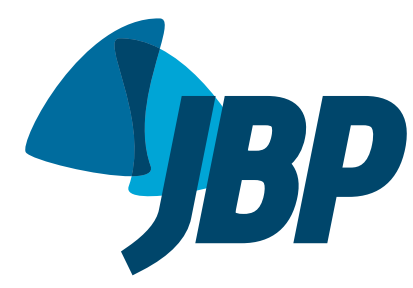

1. Novartis Biociências S.A. Brasil, São Paulo (SP), Brasil.

2. Hospital da Criança de Brasília José Alencar, Brasília (DF), Brasil.

3. Departamento de Pneumologia, Hospital Universitário Pedro Ernesto da Universidade do Estado do Rio de Janeiro, (RJ), Brasil.

4. Unidade de Pneumologia, Instituto da Criança, Hospital das Clínicas, Faculdade de Medicina, Universidade de São Paulo, São Paulo (SP), Brasil.

5. Hospital Israelita Albert Einstein, São Paulo (SP), Brasil.

6. Faculdade de Ciências Médicas, Santa Casa de São Paulo, São Paulo (SP), Brasil

7. Associação Mineira de Assistência a Mucoviscidose - AMAM Belo Horizonte (MG), Brasil.

8. Hospital de Clínicas, Porto Alegre (RS), Brasil.

9. Universidade Federal do Rio Grande do Sul, Porto Alegre (RS), Brasil.

10. Laboratório de Fisiologia Pulmonar Centro de Investigação em Pediatria, Faculdade de Ciências Médicas, Universidade Estadual de Campinas, Campinas (SP), Brasil

a. (D) http://orcid.org/0000-0003-4145-9945

b. (D) http://orcid.org/0000-0001-5595-351X

c. (ID) http://orcid.org/0000-0001-8598-4878

d. (D) http://orcid.org/0000-0001-8431-1997

e. (D) http://orcid.org/0000-0001-5284-3585

f. (D) http://orcid.org/0000-0001-5670-0434

g. (ID) http://orcid.org/0000-0003-0252-7570

h. (D) http://orcid.org/0000-0002-3387-5642

Submitted: 27 October 2017

Accepted: 23 September 2018

Study carried out in the Novartis

Biociências S.A., São Paulo (SP), Brasil.

\section{Microbiological contamination of nebulizers used by cystic fibrosis patients: an underestimated problem}

Barbara Riquena ${ }^{1, a}$, Luciana de Freitas Velloso Monte ${ }^{2, b}$, Agnaldo José Lopes ${ }^{3, c}$, Luiz Vicente Ribeiro Ferreira da Silva-Filho ${ }^{4,5, \mathrm{~d}}$, Neiva Damaceno ${ }^{6, \mathrm{e}}$, Evanirso da Silva Aquino ${ }^{7, f}$, Paulo Jose Cauduro Marostica ${ }^{8,9,9}$, José Dirceu Ribeiro ${ }^{10, h}$

\begin{abstract}
Objective: Home nebulizers are routinely used in the treatment of patients with cystic fibrosis (CF). This study aims to evaluate the contamination of nebulizers used for CF patients, that are chronically colonized by Pseudomonas aeruginosa, and the association of nebulizer contamination with cleaning, decontamination and drying practices. Methods: A cross-sectional, observational, multicenter study was conducted in seven CF reference centers in Brazil to obtain data from medical records, structured interviews with patients/caregivers were performed, and nebulizer's parts (interface and cup) were collected for microbiological culture. Results: overall, 77 CF patients were included. The frequency of nebulizer contamination was $71.6 \%$. Candida spp. (52.9\%), Stenotrophomonas maltophilia (11.9\%), non-mucoid P. aeruginosa $(4.8 \%)$, Staphylococcus aureus (4.8\%) and Burkholderia cepacia complex (2.4\%) were the most common isolated pathogens. The frequency of nebulizers' hygiene was $97.4 \%$, and $70.3 \%$ of patients reported cleaning, disinfection and drying the nebulizers. The use of tap water in cleaning method and outdoor drying of the parts significantly increased (9.10 times) the chance of nebulizers' contamination. Conclusion: Despite the high frequency hygiene of the nebulizers reported, the cleaning and disinfection methods used were often inadequate. A significant proportion of nebulizers was contaminated with potentially pathogenic microorganisms for CF patients. These findings support the need to include patients/caregivers in educational programs and / or new strategies for delivering inhaled antibiotics.
\end{abstract}

Keywords: Cystic fibrosis; Pseudomonas aeruginosa; Nebulizers and vaporizers; Equipment contamination; Decontamination.

\section{INTRODUCTION}

Cystic fibrosis (CF) is an autosomal recessive disease, which predominantly affects Caucasians and is potentially fatal. ${ }^{(1,2)}$ Brazilian incidence estimates vary across the country, from $1 / 1,587-1 / 32,258$ live births. ${ }^{(3)}$ Chronic respiratory infections are the leading cause of death among these patients and Pseudomonas aeruginosa is the pathogen most frequently associated with clinical deterioration. ${ }^{(4)}$
Home nebulizers are widely used by CF patients as part of their treatment, to deliver mucolytics and antibiotics directly to the lungs. ${ }^{(5,6)}$ Epidemiological studies reported the use of inhaled treatment among $35.8 \%-82.1 \%$ of CF patients, depending on the type of medication. ${ }^{(7)}$ Several studies which assessed contamination of the equipment and frequency of at least one pathogen reported a high rate of nebulizer contamination, around $60 \%$. $^{(8-14)}$ Home nebulizer use was associated with a 28.5 -fold greater

Correspondence to:

Barbara Riquena. Novartis Pharma Brasil, Av. Prof. Vicente Rao, 90, Brooklin, CEP 04636-000, São Paulo, SP, Brasil.

Tel.: +55 11 5532-4552. E-mail: publicação.brasil@novartis.com

Financial support: Novartis Biociências SA. 
chance of bacterial contamination. (15) Nebulizers might be the primary source of colonization for some patients, ${ }^{(14)}$ since proper cleaning instructions are not adequately followed. ${ }^{(10)}$ Therefore, instead of acting as an auxiliary tool for the treatment of $\mathrm{CF}$, nebulizers can become a harmful device if not properly managed.

International guidelines and, recently, the CF Brazilian guideline point to the importance of proper care with nebulizers. ${ }^{(16,17)}$ Cultural, socioeconomic, and even climatic differences can interfere with the quality of care with nebulizers and consequently their contamination. ${ }^{12,14)}$ In this way, knowledge of regional particularities is essential, since few studies about the contamination profile of home nebulizers are available in developing countries, mainly in Brazil. This study aims to evaluate the contamination of nebulizers used for CF patients chronically colonized by $P$. aeruginosa and its association with cleaning, decontamination and drying practices.

\section{METHODS}

\section{Ethics approval}

The study was approved by the independent Ethics Committees of each participating site. Informed consent (assent, for those $<18$ years old) was signed for each patient before any study procedures.

\section{Study design}

Cross-sectional, observational, multicenter study was conducted in seven CF Brazilian reference centers. Data collection was performed from January 2013 to December 2014. Data were obtained from three sources (swab samples from nebulizers, medical records and interviews). Patients were asked to carry the nebulizer to the center during a routine visit. At this point, they were not informed about sample collection to avoid an information bias caused by unusual cleaning of the equipment. Swab samples for culture were collected from interface (mouthpiece/mask) and cup to evaluate nebulizers' contamination. Medical records were revised to collect CF data about diagnosis, ShwachmanKulczycki score, pulmonary function, age, gender, ethnic groups and patients' body mass index (BMI). During a face-to-face structured interview, patient/ caregiver (depending on who was responsible for cleaning the device) answered questions about aspects related to nebulizer hygiene routine, nebulizer use and sociodemographic characteristics. For this study, the nebulizer hygiene process was considered as the following steps: cleaning, disinfection and drying.

\section{Eligibility criteria}

Eligible patients were those $\geq 6$ years old; diagnosed with CF confirmed by sweat chloride test above $60 \mathrm{mEq} /$ $\mathrm{dl}$ or evidence of at least two CF causing mutations and on inhaled antibiotics therapy due to chronic airway colonization by $P$. aeruginosa. Patients should be using nebulizer of the brand PARI ${ }^{\circledR}$ and compressor PRONEB ${ }^{\circledR}$ for at least 3 consecutive months. Patients who did not use the nebulizer for inhaled antibiotic therapy for more than 30 days; who shared the nebulizer with other people; had participated of a similar study in the last 12 months and currently participating in a clinical study were excluded.

\section{Sample collection and laboratory testing}

Nebulizer assessment was performed between Day 21 and Day 28 from the OFF period of inhaled antibiotic therapy. Samples were collected via swab using aseptic technique described in laboratory's manual and shipped in Amies culture media, which is a liquid used to maintain the viability of microorganisms during transport. ${ }^{(18)}$ Samples were shipped to a central laboratory and analyzed for the presence of pathogens in CF such as $P$. aeruginosa (mucoid and non-mucoid strains), B. cepacia complex, Stenotrophomonas maltophilia, Staphylococcus aureus (sensitive and resistant to methicillin), Acinetobacter sp., Chromobacter sp. and fungus. Culture mediums used for bacteria isolation were blood agar ${ }^{(19)}$ and chocolate agar ${ }^{(20)}$ and selective agar to $B$. cepacia complex. Bacterial identification was performed on Vitek 2 or mass spectrometry (Vitek MS), both automated systems. ${ }^{(21-23)}$ Antibiotic susceptibility testing was performed on Vitek 2, using a manual confirmation when applicable in accordance with guidelines from Clinical and Laboratory Standards Institute. The culture mediums used to isolate fungus were sabouraud and mycosel agar. These culture mediums had been previously used in CF. $(24,25)$ Nonfermenting Gram-negative bacilli not identified in the culture mediums were analyzed and identified through molecular biology. ${ }^{(26)}$

\section{Statistical analysis}

Considering the contamination risk of $63 \%$, ${ }^{(12)}$ a sample size of 80 patients would provide a $95 \%$ confidence interval (CI) with a margin of error of $\pm 10.5 \%$ to assess the study primary endpoint. However, due to recruitment difficulties, the study was interrupted with 77 patients, which provided a $95 \%$ CI with a margin of error of $\pm 10.7 \%$ (still lower than the reference study, which CI was $14.3 \%$, considering the same contamination risk of $63 \%$ ).

Descriptive analysis was performed through measures of central tendency, measures of dependency and measures of dispersion to quantitative variables, and frequency to qualitative variables. To determine the association among variables were estimated $p$-value by Pearson's Chi-square test and the odds ratio by binary logistic regression. Data were analyzed using the statistic software Stata MP11 and R Project 2.13.1, using a $95 \% \mathrm{CI}$ and $\mathrm{p}$-value $\leq 0.05$ as significant.

\section{RESULTS}

\section{Patients' demographic and disease characteristics}

Demographic and disease characteristics of included patients are shown in Table 1. 


\section{Nebulizers' contamination profile}

Microbiological contamination profile of home nebulizers was grouped in accordance with nebulizer's part (interface, cup or any part of the device) and pathogen contaminant (bacteria, fungus or any contamination) - Table 2. Assessing any nebulizers' parts there was a prevalence of $71.6 \%(95 \% \mathrm{CI}=$ 61.3- 81.9) pathogen contamination in the study. According to nebulizer part, frequency observed was $60.8 \%(95 \% \mathrm{CI}=49.7-71.9)$ in interface and $62.2 \%$ $(95 \% \mathrm{CI}=51.2-73.2)$ in cup.

Bacterial contamination was observed in $56.8 \%$ $(95 \% \mathrm{CI}=45.5-68.1)$ of the cases and fungal contamination in $45.9 \%$ ( $95 \% \mathrm{CI}=34.5-57.3)$. Among those with bacterial contamination, Gram-negative bacteria was the most commonly found pathogen
(85.7\%; 95\%CI $=75.1-96.3)$. The most frequently observed Gram-negative bacterial species were Pseudomonas spp. $(31.0 \% ; 95 \% \mathrm{CI}=17.0-45.0)$ and Acinetobacter spp. $(21.4 \% ; 95 \% \mathrm{CI}=9.0-33.8)$. Staphylococcus spp. $(21.4 \% ; 95 \% \mathrm{CI}=9.0-33.8)$ and Micrococcus spp. $(14.3 \% ; 95 \% \mathrm{CI}=3.7-24.9)$ were the most frequent Gram-positive bacterial species. Candida spp. was the most frequently observed fungus $(52.9 \% ; 95 \% \mathrm{CI}=36.1-69.7)$, followed by environmental contaminant fungus $(26.5 \% ; 95 \% \mathrm{CI}=$ 11.7-41.3). Other pathogens of interest and with an important role in clinical practice were also isolated: non-mucoid $P$. aeruginosa $(4.8 \% ; 95 \% \mathrm{CI}=0.0-11.3)$, B. cepacia complex $(2.4 \% ; 95 \% \mathrm{CI}=0.0-7.0), \mathrm{S}$. maltophilia $(11.9 \% ; 95 \% \mathrm{CI}=2.1-21.7)$ and $S$. aureus (4.8\%; 95\%CI $=0.0-11.3)$ - Table 2 .

Table 1. Cystic fibrosis patients' profile.

\begin{tabular}{|c|c|}
\hline Characteristics & $\mathbf{N}(\%)$ \\
\hline Age (years) & $15.8 \pm 6.5$ \\
\hline \multicolumn{2}{|l|}{ Gender } \\
\hline Male & $44(57.9)$ \\
\hline Female & $32(42.1)$ \\
\hline \multicolumn{2}{|l|}{ Ethnic groups } \\
\hline Caucasian & $51(66.2)$ \\
\hline Afro-descendent & $11(14.3)$ \\
\hline Mixed (Pardo) & $13(17.1)$ \\
\hline No information & $2(2.6)$ \\
\hline \multicolumn{2}{|l|}{ Educational level of the responsible for cleaning the nebulizer } \\
\hline Never been to school & -- \\
\hline Incomplete elementary school & $19(25.0)$ \\
\hline Complete elementary school & $6(7.9)$ \\
\hline Incomplete high school & $7(9.2)$ \\
\hline Complete high school & $25(32.9)$ \\
\hline Incomplete graduation & $7(9.2)$ \\
\hline Complete graduation & $12(15.8)$ \\
\hline Monthly Family Income (BRL\$) & $2,972.3 \pm 2,975.4$ \\
\hline Number of people who cohabit & $3.9 \pm 1.4$ \\
\hline Siblings living in the same residence & $0.9 \pm 1.0$ \\
\hline Rooms in the house & $3.7 \pm 1.6$ \\
\hline Distance between the household and the treatment center $(\mathrm{km})$ & $56.3 \pm 92.2$ \\
\hline $\operatorname{BMI}\left(\mathrm{kg} / \mathrm{m}^{2}\right)$ & $18.7 \pm 3.65$ \\
\hline Height (cm) & $155.0 \pm 17.2$ \\
\hline Weight (kg) & $49.7 \pm 16.1$ \\
\hline Time since CF diagnosis (years) & $10.2 \pm 5.68$ \\
\hline \multicolumn{2}{|l|}{ Shwachman-Kulczycki Score } \\
\hline Excellent & $4(5.2)$ \\
\hline Good & $10(13.0)$ \\
\hline Medium & $11(14.3)$ \\
\hline Moderate & $6(7.8)$ \\
\hline Severe & $1(1.3)$ \\
\hline \multicolumn{2}{|l|}{ Pulmonary function test } \\
\hline $\mathrm{FEV}_{1}(\%)$ & $61.3 \pm 22.9$ \\
\hline FVC (\%) & $75.5 \pm 24.1$ \\
\hline $\mathrm{FEV}_{1} / \mathrm{FVC}(\%)$ & $76.8 \pm 19.4$ \\
\hline
\end{tabular}

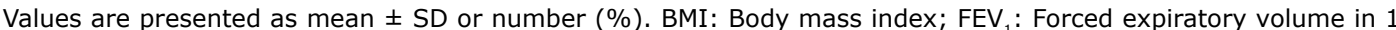
second; FVC: Forced vital capacity; FEV ${ }_{1}$ /FVC: ratio of forced expiratory volume in 1 second to forced vital capacity. 
Table 2. Contamination profile of home nebulizers of cystic fibrosis patients: type of fungus and bacteria according to place of contamination.

\begin{tabular}{|c|c|c|c|c|c|c|}
\hline \multirow[t]{2}{*}{ Characteristics } & \multicolumn{2}{|c|}{ Interface } & \multicolumn{2}{|c|}{ Cup } & \multicolumn{2}{|c|}{$\begin{array}{l}\text { Any part of the } \\
\text { device }\end{array}$} \\
\hline & $\mathbf{N}(\%)$ & $95 \% \mathrm{Cl}$ & $\mathbf{N}(\%)$ & $95 \% \mathrm{CI}$ & $\mathbf{N}(\%)$ & $95 \% \mathrm{Cl}$ \\
\hline Any contamination & $45(60.8)$ & $49.7-71.9$ & $46(62.2)$ & $51.2-73.2$ & $53(71.6)$ & $61.3-81.9$ \\
\hline Bacterial contamination & $35(47.3)$ & $35.9-58.7$ & $37(50.0)$ & $38.6-61.4$ & $42(56.8)$ & $45.5-68.1$ \\
\hline Gram-negative bacteria ${ }^{a}$ & $25(71.4)$ & $56.4-86.4$ & $23(62.2)$ & $46.6-77.8$ & $36(85.7)$ & $75.1-96.3$ \\
\hline Pseudomonas spp. ${ }^{a}$ & $5(14.3)$ & $2.7-25.9$ & $9(24.3)$ & $10.5-38.1$ & $13(31.0)$ & $17.0-45.0$ \\
\hline $\begin{array}{l}\text { Non-mucoid Pseudomonas } \\
\text { aeruginosa }{ }^{\mathrm{a}}\end{array}$ & -- & -- & $2(5.4)$ & $0.0-12.7$ & $2(4.8)$ & $0.0-11.3$ \\
\hline Mucoid Pseudomonas aeruginosa ${ }^{\mathrm{a}}$ & -- & -- & -- & -- & -- & -- \\
\hline Other Pseudomonas ${ }^{\mathrm{a}}$ & $5(14.3)$ & $2.7-25.9$ & 7 (18.9) & $6.3-31.5$ & $10(23.8)$ & $10.9-36.7$ \\
\hline Acinetobacter spp. ${ }^{\mathrm{a}}$ & $8(22.9)$ & $9.0-36.8$ & 7 (18.9) & $6.3-31.5$ & $9(21.4)$ & $9.0-33.8$ \\
\hline Stenotrophomonas spp. ${ }^{a}$ & $5(14.3)$ & $2.7-25.9$ & $4(10.8)$ & $0.8-20.8$ & 5 (11.9) & $2.1-21.7$ \\
\hline Stenotrophomonas maltophilia & $5(14.3)$ & $2.7-25.9$ & $4(10.8)$ & $0.8-20.8$ & 5 (11.9) & $2.1-21.7$ \\
\hline Enterobacter spp. ${ }^{a}$ & $3(8.6)$ & $0.0-17.9$ & $4(10.8)$ & $0.8-20.8$ & 4 (11.9) & $2.1-21.7$ \\
\hline Klebsiella spp. ${ }^{a}$ & $1(2.9)$ & $0.0-8.5$ & $4(10.8)$ & $0.8-20.8$ & $4(9.5)$ & $0.6-18.4$ \\
\hline Sphingobacterium spp. ${ }^{a}$ & $1(2.9)$ & $0.0-8.5$ & $1(2.7)$ & $0.0-7.9$ & $2(4.8)$ & $0.0-11.3$ \\
\hline Delftia spp. ${ }^{a}$ & $1(2.9)$ & $0.0-8.5$ & $2(5.4)$ & $0.0-12.7$ & $2(4.8)$ & $0.0-11.3$ \\
\hline 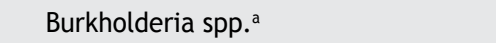 & -- & -- & $1(2.7)$ & $0.0-7.9$ & $1(2.4)$ & $0.0-7.0$ \\
\hline Burkholderia cepacia co & -- & -- & $1(2.7)$ & $0.0-7.9$ & $1(2.4)$ & $0.0-7.0$ \\
\hline Other ${ }^{\mathrm{a}}$ & $12(34.3)$ & $18.6-50.0$ & $9(24.3)$ & $10.5-38.1$ & $15(35.7)$ & $21.2-50.2$ \\
\hline Chryseobacterium indologenes ${ }^{\mathrm{a}}$ & $5(14.3)$ & $2.7-25.9$ & $4(10.8)$ & $0.8-20.8$ & 5 (11.9) & $2.1-21.7$ \\
\hline Sphingomonas paucimobilis ${ }^{\mathrm{a}}$ & $2(5.7)$ & $0.0-13.4$ & $1(2.7)$ & $0.0-7.9$ & $3(7.1)$ & $0.0-14.9$ \\
\hline Pantoea agglomerans ${ }^{\mathrm{a}}$ & $1(2.9)$ & $0.0-8.5$ & $1(2.7)$ & $0.0-7.9$ & $2(4.8)$ & $0.0-11.3$ \\
\hline Aeromonas hydrophila a & $1(2.9)$ & $0.0-8.5$ & -- & -- & $1(2.4)$ & $0.0-7.0$ \\
\hline Comamonas testosteron $^{\mathrm{a}}$ & -- & -- & $1(2.7)$ & $0.0-7.9$ & $1(2.4)$ & $0.0-7.0$ \\
\hline Moraxella osloensis ${ }^{\mathrm{a}}$ & $1(2.9)$ & $0.0-8.5$ & -- & -- & $1(2.4)$ & $0.0-7.0$ \\
\hline Rhizobium radiobacter ${ }^{\mathrm{a}}$ & $1(2.9)$ & $0.0-8.5$ & $1(2.7)$ & $0.0-7.9$ & $1(2.4)$ & $0.0-7.0$ \\
\hline Serratia marcescens ${ }^{\mathrm{a}}$ & $1(2.9)$ & $0.0-8.5$ & $1(2.7)$ & $0.0-7.9$ & $1(2.4)$ & $0.0-7.0$ \\
\hline Gram-positive bacteria ${ }^{a}$ & $10(28.6)$ & $13.6-43.6$ & $10(27.0)$ & $12.7-41.3$ & $17(40.5)$ & $25.7-55.3$ \\
\hline Staphylococcus spp. ${ }^{a}$ & $6(17.1)$ & $4.6-29.6$ & $7(18.9)$ & $6.3-31.5$ & $9(21.4)$ & $9.0-33.8$ \\
\hline Staphylococcus aureus ${ }^{\mathrm{a}}$ & $2(5.7)$ & $0.0-13.4$ & $2(5.4)$ & $0.0-12.7$ & $2(4.8)$ & $0.0-11.3$ \\
\hline $\begin{array}{l}\text { Oxacillin-resistant coagulase- } \\
\text { negative Staphylococcus aureus }\end{array}$ & $1(2.9)$ & $0.0-8.5$ & $1(2.7)$ & $0.0-7.9$ & $1(2.4)$ & $0.0-7.0$ \\
\hline Other Staphylococcus ${ }^{a}$ & $3(8.6)$ & $0.0-17.9$ & $4(10.8)$ & $0.8-20.8$ & $6(14.3)$ & $3.7-24.9$ \\
\hline Micrococcus spp..$^{a}$ & $4(11.4)$ & $0.9-21.9$ & $4(10.8)$ & $0.8-20.8$ & $6(14.3)$ & $3.7-24.9$ \\
\hline Bacillus spp. $^{a}$ & $3(8.6)$ & $0.0-17.9$ & $4(10.8)$ & $0.8-20.8$ & $5(11.9)$ & $2.1-21.7$ \\
\hline Streptococcus spp. ${ }^{a}$ & -- & -- & $1(2.7)$ & $0.0-7.9$ & $1(2.4)$ & $0.0-7.0$ \\
\hline Fungal contamination & $20(27.0)$ & $16.9-37.1$ & $28(37.8)$ & $26.8-48.8$ & $34(45.9)$ & $34.5-57.3$ \\
\hline Candida spp. ${ }^{\text {b }}$ & $11(55.0)$ & $33.2-76.8$ & $14(50.0)$ & $31.5-68.5$ & $18(52.9)$ & $36.1-69.7$ \\
\hline Non-albicans Candida spp. ${ }^{\mathrm{b}}$ & $9(45.0)$ & $23.2-66.8$ & $14(50.0)$ & $31.5-68.5$ & $16(47.1)$ & $30.3-63.9$ \\
\hline Candida albicans ${ }^{\mathrm{b}}$ & $1(5.0)$ & $0.0-14.6$ & -- & $-\cdot$ & $1(2.9)$ & $0.0-8.5$ \\
\hline Candida spp. ${ }^{\text {b }}$ & $1(5.0)$ & $0.0-14.6$ & -- & -- & $1(2.9)$ & $0.0-8.5$ \\
\hline Environmental contaminant fungus ${ }^{\mathrm{b}}$ & $4(20.0)$ & $2.5-37.5$ & $8(28.6)$ & $11.9-45.3$ & $9(26.5)$ & $11.7-41.3$ \\
\hline Other ${ }^{\mathrm{b}}$ & $7(35.0)$ & $14.1-55.9$ & $7(25.0)$ & $9.0-41.0$ & $10(29.4)$ & $14.1-44.7$ \\
\hline Cladosporium sp. ${ }^{\mathrm{b}}$ & $3(15.0)$ & $0.0-30.6$ & $3(10.7)$ & $0.0-22.1$ & $4(11.8)$ & $1.0-22.6$ \\
\hline Rhodotorula spp. ${ }^{\text {b }}$ & $3(15.0)$ & $0.0-30.6$ & $3(10.7)$ & $0.0-22.1$ & $4(11.8)$ & $1.0-22.6$ \\
\hline Aspergillus niger ${ }^{\mathrm{b}}$ & -- & -- & $1(3.6)$ & $0.0-10.5$ & $1(2.9)$ & $0.0-8.5$ \\
\hline Penicillium sp. ${ }^{\mathrm{b}}$ & $1(5.0)$ & $0.0-14.6$ & -- & -- & $1(2.9)$ & $0.0-8.5$ \\
\hline
\end{tabular}

aproportion calculated among number of interfaces $(\mathrm{N}=35)$, cups $(\mathrm{N}=37)$ and any part of nebulizer $(\mathrm{N}=42)$ with bacterial contamination. bProportion calculated among number of interfaces $(\mathrm{N}=20)$, cups $(\mathrm{N}=28)$ and any part of nebulizer $(\mathrm{N}=34)$ with bacterial contamination.

Characteristics of nebulizers' hygiene

Considering characteristics of nebulizers use, frequency of nebulizer hygiene and method employed,
76 patients answered the interview questions. Patients reported the use of the following medications in nebulizer: dornase alfa $(\mathrm{N}=72 ; 94.7 \%)$, tobramycin 
inhaler solution $(\mathrm{N}=64 ; 84.2 \%)$, hypertonic saline solution ( $N=17 ; 22.4 \%)$, colistin ( $N=15 ; 19.7 \%)$, bronchodilator $(\mathrm{N}=5 ; 6.6 \%)$ and isotonic saline solution $(\mathrm{N}=1 ; 1.3 \%)$. All patients reported to use only one drug during each nebulization.

Regarding the nebulizers' parts replacement, most patients had not performed it in the analyzed equipment $(\mathrm{N}=48 ; 63.2 \%)$ and the reported reasons were: recommended interval to switch had not been reached $(\mathrm{N}=29 ; 60.4 \%)$; lack of knowledge about the necessity $(\mathrm{N}=12 ; 25.0 \%)$; forgetfulness $(\mathrm{N}=$ $2 ; 4.2 \%)$; and other reasons $(\mathrm{N}=7 ; 14.6 \%)$. For those who reported to replace at least one part, cup was replaced in $85.7 \%(\mathrm{~N}=24)$, hose in $64.3 \%(\mathrm{~N}$ $=18)$, interface and filter in $60.7 \%(N=17)$ of the cases, other parts in $7.1 \%(\mathrm{~N}=2)$ and all parts in $21.4 \%(N=6)$. For patients who replaced all parts, half did it after more than six months of use.

Regular nebulizer hygiene was reported by $97.4 \%$ of the cases. Among those who reported regular nebulizer hygiene, the cup was the most cited part ( $\mathrm{N}$ $=74 ; 100.0 \%)$, followed by the interface $79.7 \%(\mathrm{~N}=$ $59)$, hose $50.0 \%(\mathrm{~N}=37)$ and filter $12.2 \%(\mathrm{~N}=9)$. Most patients $(71.1 \%)$ reported to perform nebulizer hygiene process after each nebulizer's use -Table 3.

Considering each step of nebulizer hygiene, 64 $(86.5 \%)$ patients performed the cleaning process, 62 $(83.8 \%)$ patients performed the disinfection process, and $73(96.0 \%)$ patients performed the drying process. Most frequent cleaning process observed was lather and rinse under tap water $(\mathrm{N}=49 ; 76.6 \%)$. A wide variety of disinfection methods were reported and the most frequent were immersion in boiling water (24.2\%) and immersion in hypochlorite solution $(21.0 \%)$. The entire process of nebulizer hygiene, using at least one cleaning, disinfection and drying method was reported by most of the study sample (70.3\%) -Table 3.

Also, as a secondary objective of the study, the association between educational level and demographic data from patients and/or caregivers and the frequency of nebulizers cleaning was assessed and no significant differences were observed (data not shown).

\section{Relation between nebulizers' cleaning and pathogen contamination}

Bivariate analysis of the association between the nebulizers' cleaning and a positive culture for bacteria and/or fungus in the analyzed pieces are described in Table 4. A statistically significant difference in the frequency of contamination was observed for cleaning method (Only tap water $=92.9 \%$ of contamination vs. Lather and rinse under tap water $=66.0 \%$ of contamination; $\mathrm{p}=0.049$ ), performing or not disinfection (Yes $=66.7 \%$ of contamination vs. No $=100.0 \%$ of contamination; $\mathrm{p}=0.015$ ) and drying method (With a cloth, paper towels, fan/dryer or compressor/compressed air $=60.5 \%$ of contamination vs. Only outdoors $=84.4 \%$ of contamination; $\mathrm{p}=$ 0.028 ). A multivariate analysis by binary logistic regression for the factors associated to the positivity of culture was performed using the stepwise backward strategy. For this analysis, any contamination in nebulizer and the variables reported in Table 4 were included. The use only of tap water as a cleaning method increased 9-fold chance of contamination $(\mathrm{OR}=9.10 ; 95 \% \mathrm{CI}=1.01-81.77 ; \mathrm{p}=0.049)$ when compared with the use of lather and rinse under tap water. Drying outdoors increased 4.87-fold chance of contamination $(\mathrm{OR}=4.87 ; 95 \% \mathrm{CI}=1.10-21.61$; $\mathrm{p}=0.038$ ) when compared with the use of some material, such as a cloth, paper towel, fan/dryer or the compressor/compressed air.

As nebulizer drying process performed outdoor is a recommended practice, the frequency of an inadequate cleaning (none or only tap water) or disinfection (none, sodium hypochlorite or vinegar solution) was assessed. An inadequate cleaning method was observed in $26 \%$ of the sample ( $\mathrm{N}=$ $7)$, an inadequate disinfection in $40.7 \%(\mathrm{~N}=11)$, both inadequate cleaning and disinfection methods in $7.4 \%(\mathrm{~N}=2)$ and inadequate cleaning or disinfection methods in $59.2 \%(N=16)$.

\section{DISCUSSION}

In this multi-centric Brazilian study, a high prevalence of nebulizer contamination was observed among CF patients chronically colonized by $P$. aeruginosa under inhaled antibiotic on-off therapy. The role of home nebulizers as a source of contamination for patients with CF has been studied since $1987^{(8-14)}$ but the amount of good and representative data within CF Brazilian patients is scarce. In addition, a high rate of nonconformities was observed in nebulizer use by patients and caregivers. This is an important issue as inadequate cleaning of the nebulizer has been associated with its contamination. ${ }^{(12)}$

Considering the prevalence of contamination in any part of the device, previous Brazilian studies found estimates from $25.0 \%$ to $57.5 \%$, lower than those found in the current study. ${ }^{(10,13)}$ This difference can be possibly attributed to distinct clinical characteristics between populations such as severity of lung function impairment and by patients' behavior. In the present study, adequate care with nebulizers was systematically analyzed and a low rate of appropriate management was observed.

Bacteria were the main pathogenic contaminants identified in the studied devices (56.8\% of the patients), mainly the Gram-negative ones. Nevertheless, fungal contamination was also a relevant finding since $40.5 \%$ of patients were contaminated by large fungal species variety. Current literature, ranging several countries, has also shown a wide variety of bacterial specimens with heterogeneous results, varying the higher prevalence between Gram-positive and Gram-negative bacteria. Acinetobacter spp. and Pseudomonas spp. were the most frequently reported Gram-negative bacteria and Staphylococcus spp., was the most 
Table 3. Hygienization profile of home nebulizers of cystic fibrosis patients.

\begin{tabular}{|c|c|}
\hline Characteristics & $\mathbf{N}(\%)$ \\
\hline \multicolumn{2}{|l|}{ Nebulizer is regularly hygienized } \\
\hline Yes & $74(97.4)$ \\
\hline No & $2(2.6)$ \\
\hline \multicolumn{2}{|l|}{ Nebulizer parts usually hygienized } \\
\hline Interface & 59 (79.7) \\
\hline Cup & $74(100.0)$ \\
\hline Hose & $37(50.0)$ \\
\hline Filter & $9(12.2)$ \\
\hline Other & $1(1.4)$ \\
\hline \multicolumn{2}{|l|}{ Hygienization after each use } \\
\hline Yes & $54(71.1)$ \\
\hline No & $20(26.3)$ \\
\hline No information & $2(2.6)$ \\
\hline \multicolumn{2}{|l|}{ Length of each cleaning/disinfection } \\
\hline Less than 15 minutes & $44(57.9)$ \\
\hline More than 15 minutes & $30(39.5)$ \\
\hline No information & $2(2.6)$ \\
\hline Cleaning & $64(86.5)$ \\
\hline Only tap water & $15(23.4)$ \\
\hline Lather and rinse under tap water & $49(76.6)$ \\
\hline Disinfection & $62(83.8)$ \\
\hline Immersion in boiling water & $15(24.2)$ \\
\hline Immersion in sodium hypochlorite solution & $13(21.0)$ \\
\hline Immersion in boiling water and Immersion in sodium hypochlorite solution & $11(17.7)$ \\
\hline Immersion in vinegar solution & $5(8.1)$ \\
\hline Immersion in boiling water and Immersion in alcohol & $4(6.5)$ \\
\hline Immersion in boiling water and Immersion in alcohol and Immersion in vinegar solution & $1(1.6)$ \\
\hline Immersion in boiling water and Immersion in vinegar solution & $3(4.8)$ \\
\hline Immersion in alcohol & $2(3.2)$ \\
\hline Immersion in sodium hypochlorite solution and Microwave & $2(3.2)$ \\
\hline $\begin{array}{l}\text { Immersion in boiling water and Immersion in sodium hypochlorite solution and Immersion in } \\
\text { alcohol }\end{array}$ & $2(3.2)$ \\
\hline $\begin{array}{l}\text { Immersion in boiling water and Immersion in sodium hypochlorite solution and Immersion in } \\
\text { vinegar solution }\end{array}$ & $2(3.2)$ \\
\hline $\begin{array}{l}\text { Immersion in boiling water and Immersion in sodium hypochlorite solution and Immersion in } \\
\text { vinegar solution and Immersion in alcohol }\end{array}$ & $1(1.6)$ \\
\hline Immersion in sodium hypochlorite solution and Immersion in alcohol & $1(1.6)$ \\
\hline Drying & $73(98.6)$ \\
\hline Only outdoors & $32(43.8)$ \\
\hline With a cloth & $20(27.4)$ \\
\hline With paper towel & $19(26.0)$ \\
\hline With a fan/dryer & $1(1.4)$ \\
\hline With the compressor/compressed air & $1(1.4)$ \\
\hline \multicolumn{2}{|l|}{ Hygienization method } \\
\hline Clean, disinfection and dry & $52(70.3)$ \\
\hline Clean and dry & $11(14.9)$ \\
\hline Disinfection and dry & $10(13.5)$ \\
\hline Only clean & $1(1.4)$ \\
\hline
\end{tabular}

frequent Gram-positive bacteria. ${ }^{(8-14)}$ Previous Brazilian studies found Staphylococcus spp. as the most frequent pathogen contaminating nebulizers. ${ }^{(10,13)}$ In the present study, the assessment of nebulizer contamination was performed in a significantly larger population, although still pediatric, older than in previous studies.
Furthermore, it is well described the relationship of increasing airway colonization by Gram-negative bacteria in CF patients with age increase, associated with a decrease by Gram-positive.(1) This behavior might interfere in the nebulizer contamination and may explain the different results in this field. 
Table 4. Association between nebulizers' hygienization and positivity of culture.

\begin{tabular}{|c|c|c|c|}
\hline \multirow[t]{2}{*}{ Characteristics } & \multicolumn{2}{|c|}{$\begin{array}{l}\text { Contamination by fungus or bacteria at } \\
\text { least in one part of the nebulizer }\end{array}$} & \multirow[t]{2}{*}{ p-value } \\
\hline & $\begin{array}{l}\text { Yes } \\
\text { N (\%) }\end{array}$ & $\begin{array}{l}\text { No } \\
\text { N (\%) }\end{array}$ & \\
\hline \multicolumn{4}{|l|}{ Nebulizer parts usually hygienized ${ }^{a}$} \\
\hline Interface & $40(70.2)$ & $17(29.8)$ & 0.380 \\
\hline Cup & $51(71.8)$ & $20(28.2)$ & 0.378 \\
\hline Hose & $24(66.7)$ & $12(33.3)$ & 0.262 \\
\hline Filter & $5(55.6)$ & $4(44.4)$ & 0.221 \\
\hline Other & $1(100.0)$ & $0(--)$ & 0.536 \\
\hline \multicolumn{4}{|l|}{ Length of each hygienization } \\
\hline Less than 15 minutes & $31(72.1)$ & $12(27.9)$ & \multirow{2}{*}{0.951} \\
\hline More than 15 minutes & $20(71.4)$ & $8(28.6)$ & \\
\hline \multicolumn{4}{|l|}{ Hygienization after each use } \\
\hline Yes & $23(45.1)$ & 28 (54.9) & \multirow{2}{*}{0.710} \\
\hline No & $8(40.0)$ & $12(60.0)$ & \\
\hline \multicolumn{4}{|l|}{ Cleaning } \\
\hline Yes & $44(72.1)$ & 17 (27.9) & \multirow{2}{*}{0.839} \\
\hline No & $9(75.0)$ & $3(25.0)$ & \\
\hline \multicolumn{4}{|l|}{ Cleaning method } \\
\hline Only tap water & $13(92.9)$ & $1(7.1)$ & \multirow{2}{*}{0.049} \\
\hline Lather and rinse under tap water & $31(66.0)$ & $16(34.0)$ & \\
\hline \multicolumn{4}{|l|}{ Disinfection } \\
\hline Yes & $40(66.7)$ & $20(33.3)$ & \multirow{2}{*}{0.015} \\
\hline No & $13(100.0)$ & $0(--)$ & \\
\hline \multicolumn{4}{|l|}{ Disinfection method } \\
\hline $\begin{array}{l}\text { Immersion in boiling water and/or alcohol and/ } \\
\text { or microwave only or in association with sodium } \\
\text { hypochlorite and/or vinegar solution }\end{array}$ & $30(69.8)$ & $13(30.2)$ & \multirow{2}{*}{0.595} \\
\hline $\begin{array}{l}\text { Immersion in bleach and/or vinegar solution, without } \\
\text { other methods }\end{array}$ & $10(62.5)$ & $6(37.5)$ & \\
\hline \multicolumn{4}{|l|}{ Dry } \\
\hline Yes & $50(71.4)$ & $20(28.6)$ & \multirow{2}{*}{0.277} \\
\hline No & $3(100.0)$ & $0(--)$ & \\
\hline \multicolumn{4}{|l|}{ Drying method } \\
\hline $\begin{array}{l}\text { With a cloth, paper towel, fan/dryer or compressor/ } \\
\text { compressed air }\end{array}$ & $23(60.5)$ & $15(39.5)$ & \multirow[t]{2}{*}{0.028} \\
\hline Only outdoors & $27(84.4)$ & $5(15.6)$ & \\
\hline \multicolumn{4}{|l|}{ Hygienization method } \\
\hline No hygienization & $2(100.0)$ & $0(--)$ & \multirow{5}{*}{0.197} \\
\hline Clean, disinfection and dry & $33(66.0)$ & $17(34.0)$ & \\
\hline Only clean & $1(100.0)$ & $0(--)$ & \\
\hline Clean and dry & $10(100.0)$ & $0(--)$ & \\
\hline Disinfection and dry & $7(70.0)$ & $3(30.0)$ & \\
\hline
\end{tabular}

aSince the answers were not mutually exclusive, each option was analyzed as a dichotomous variable generating different $p$-values.

Pulmonary infection is the leading cause of death in $\mathrm{CF}$, being most cases associated to $P$. aeruginosa chronic infection. Several different sources can be implicated in airway colonization by $P$. aeruginosa, including nebulizers. ${ }^{(12,14)}$ Despite the high estimates of Pseudomonas spp detected in the present study, most cases were related to species other than $P$. aeruginosa. The prevalence of $P$. aeruginosa in the literature ranges from $0 \%-38 \%$. $^{(8-14)} \mathrm{A}$ low frequency of contamination by this pathogen in our data may probably be associated with the specific profile of our sample. Inclusion criteria definition allowed only patients with chronic colonization by $P$. aeruginosa in regular use of anti-Pseudomonas inhaled antibiotics that could interfere in bacterial growth even in the OFF month of treatment cycle.

Fungal contamination is less explored in available literature and specimens found were not clearly assessed in other studies. ${ }^{\left({ }^{8-14}\right)}$ In our sample, Candida spp. was the most common fungus found. Other 
studies reported contamination by yeast, specifically by Candida albicans (14.0\%), which was also observed

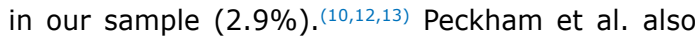
conducted a study to analyze specifically the fungal flora of nebulizers of CF adult patients and found a higher frequency of positivity $(57.7 \%)$ than reported in our study (45.9\%). (24)

We found a considerably higher frequency of patients who reported a regular hygiene of the nebulizer compared to other surveys. ${ }^{(5,9,10,13)}$ National and international guidelines emphasizes the necessity to adequate care of nebulizers. ${ }^{(16,17)}$ Cleaning steps must be performed with dish detergent soap and water, disinfection with boiling water, microwave, dishwasher, alcohol or hydrogen peroxide and lately air drying the equipment. (27) A high percentage of patients reported performing all the proposed steps. However, methods not recommended such as cleaning using only tap water, disinfection by sodium hypochlorite or vinegar solution and use of materials for drying were frequently reported. This discrepancy between the high frequency of contamination of nebulizers despite a high self-reported rate of adequate care of the devices points toward the need for better education of patients and caregivers. It is important to emphasize that self-reporting care with nebulizers does not necessarily translate into daily practice. However, in this study a high rate of not recommended nebulizer hygiene actions were observed, further reinforcing the need for improvement in the knowledge of this population. Because this is a multicenter study covering different regions of the country, we consider these data as highly relevant because it characterizes a problem found in all the centers studied and reflects a widespread problem.

A higher frequency of contamination among patients who clean the nebulizer only under tap water, do not disinfect it and dry outdoors was observed. Previous studies found that only the cleaning after each use had significant differences. ${ }^{(8,9)}$ Hohenwarter et al. compared different steam disinfection and drying methods and found recontamination only among those equipment in which an active drying (such as paper or cotton towels) was performed. ${ }^{(6)}$ A multivariate model including these characteristics was built and demonstrated that cleaning under tap water only and drying outdoors were the factors that increase the chance of contamination.

Drying outdoors is a recommended method as category II of evidence level (supported by suggestive clinical and epidemiologic studies). However, in the present study, it was associated with an increase of 4.87-fold chance of contamination. To verify if this association was related to cleaning and disinfection patterns, these frequencies among contaminated nebulizers that were dried outdoors were assessed and most patients reported at least one inadequate method of cleaning or disinfection (59.2\%). This study was not designed to test a hypothesis and available recommendations are not based on the highest evidence level, which highlights the need for conducting more studies regarding each particular component of the nebulizer hygiene process. Another Brazilian study assessed the effect of a standardized instruction regarding nebulizers' cleaning and disinfection based on the international recommendations on the frequency of contamination ${ }^{(13,28)}$ and after a single educational intervention, a significant impact was observed, reducing the frequency of contamination by $43 \%$. ${ }^{(13)}$ The proper cleaning of nebulizers can have clinical impact, since lack of cleanliness can reduce nebulizer performance and the equipment can become a potential source of contamination. (29)

There are some limitations in our study. Although this was a multicenter study with CF centers from different regions in Brazil, it was not possible to cover all states of the country. Another limitation refers to the request for patients to bring their nebulizers to assessment by the CF staff. Patients were not aware of the objective of the study before arriving in CF clinic, but we cannot exclude unusual cleaning before visit and information bias due to fear of reporting known misconduct acts to the study team. In addition, no viral agents were tested in this study although the relevance of transmission of this type of pathogen by nebulizer is yet not clear. Finally, data from patients' sputum culture was not assessed. Therefore, the relationship between airway and nebulizer contamination in the present study could not be determined.

In conclusion, high prevalence of contamination in CF nebulizers was observed despite the reports of elevated frequency of nebulizer hygiene. Most patients reported wrong cleaning techniques, emphasizing that CF team should be aware about this problem and intensify educational programs. Airway infection is one of the most important issues in CF management and several strategies should be stimulated to avoid it. The present study highlights that nebulizers are still a potential source of infection for CF patients.

Therefore, better knowledge about this area should be encouraged between patients and caregivers and/ or new strategies for inhaled antibiotic delivery, such as dry powder formulations, should be implemented.

\section{AKNOWLEDGEMENTS}

This study was funded by Novartis Biociencias S.A., Brazil assistance on study development was provided by ANOVA and manuscript preparation by EUROTRIALS Brazil. The authors thank the staff from the participating clinical centers (Adriana Della-Zuana, Licia Cristine Marinho França, Núbia Cardoso Peixoto, Patricia Yuki Watanabe de Medeiros, Carla Cristina Souza Gomez and Maria Angela Ribeiro) and also from Novartis Biociencias S.A., Brazil (Glaucimar Basaglia, Paula Simões Bruna Abreu Crippa, Nadine Cordeiro Pinho). We are grateful to patients and their relatives for their participation in the study. 


\section{REFERENCES}

1. Spoonhower KA, Davis PB. Epidemiology of cystic fibrosis. Clin Chest Med. 2016;37(1):1-8. http://dx.doi.org/10.1016/j.ccm.2015.10.002. PMid:26857763.

2. Davies JC, Ebdon A-M, Orchard C. Recent advances in the management of cystic fibrosis. Arch Dis Child. 2014;99(11):1033-6. http://dx.doi.org/10.1136/archdischild-2013-304400. PMid:24996790.

3. Raskin S, Pereira-Ferrari L, Reis FC, Abreu F, Marostica P, Rozov T, et al. Incidence of cystic fibrosis in five different states of Brazil as determined by screening of p.F508del, mutation at the CFTR gene in newborns and patients. J Cyst Fibros. 2008;7(1):15-22. http://dx.doi. org/10.1016/j.jcf.2007.03.006. PMid:17544945.

4. Pressler T, Bohmova C, Conway S, Dumcius S, Hielte L, Høiby N, et al. Chronic Pseudomonas aeruginosa infection definition: EuroCareCF Working Group report. J Cyst Fibros. 2011;10(Suppl 2):75-8. http:// dx.doi.org/10.1016/S1569-1993(11)60011-8. PMid:21658646.

5. Jarvis S, Ind PW, Thomas C, Goonesekera S, Haffenden R, Abdolrasouli A, et al. Microbial contamination of domiciliary nebulisers and clinical implications in chronic obstructive pulmonary disease. BMJ Open Respir Res. 2014;1(1):e000018. http://dx.doi. org/10.1136/bmjresp-2013-000018. PMid:25478172.

6. Hohenwarter K, Prammer W, Aichinger W, Reychler G. An evaluation of different steam disinfection protocols for cystic fibrosis nebulizers. $J$ Cyst Fibros. 2016;15(1):78-84. http://dx.doi.org/10.1016/j. jcf.2015.07.005. PMid:26233897.

7. Cystic Fibrosis Foundation. Patient registry 2011 - Annual data report. Bethesda: CFF; 2011

8. Pitchford KC, Corey M, Highsmith AK, Perlman R, Bannatyne R, Gold $R$, et al. Pseudomonas species contamination of cystic fibrosis patients' home inhalation equipment. J Pediatr. 1987;111(2):212-6. http://dx.doi.org/10.1016/S0022-3476(87)80069-0. PMid:3612391.

9. Blau $H$, Mussaffi $H$, Mei Zahav M, Prais D, Livne M, Czitron BM, et al. Microbial contamination of nebulizers in the home treatment of cystic fibrosis. Child Care Health Dev. 2007;33(4):491-5. http://dx.doi. org/10.1111/j.1365-2214.2006.00669.x. PMid:17584406.

10. Brzezinski LX, Riedi CA, Kussek P, Souza HH, Rosário N. Nebulizers in cystic fibrosis: a source of bacterial contamination in cystic fibrosis patients? J Bras Pneumol. 2011;37(3):341-7. http://dx.doi. org/10.1590/S1806-37132011000300010. PMid:21755189.

11. Rosenfeld M, Emerson J, Astley S, Joy P, Williams-Warren J, Standaert TA, et al. Home nebulizer use among patients with cystic fibrosis. J Pediatr. 1998;132(1):125-31. http://dx.doi.org/10.1016/ S0022-3476(98)70497-4. PMid:9470013.

12. Vassal $S$, Taamma R, Marty N, Sardet A, D'Athis $P$, Brémont $F$, et al. Microbiologic contamination study of nebulizers after aerosol therapy in patients with cystic fibrosis. Am J Infect Control. 2000;28(5):34751. http://dx.doi.org/10.1067/mic.2000.110214. PMid:11029133.

13. Della Zuana A, Garcia DO, Juliani RC, Silva LV Fo. Effect that an educational program for cystic fibrosis patients and caregivers has on the contamination of home nebulizers. J Bras Pneumol. 2014;40(2):119-27. http://dx.doi.org/10.1590/S180637132014000200004 . PMid:24831395.

14. Hutchinson GR, Parker S, Pryor JA, Duncan-skingle F, Hoffman PN, Hodson ME, et al. Home-use nebulizers: a potential primary source of burkholderia cepacia and other colistin-resistant, gramnegative bacteria in patients with cystic fibrosis. J Clin Microbiol. 1996;34(3):584-7. PMid:8904419.

15. Burdge DR, Nakielna EM, Noble MA. Case-control and vector studies of nosocomial acquisition of Pseudomonas cepacia in adult patients with cystic fibrosis. Infect Control Hosp Epidemiol. 1993;14(3):12730. http://dx.doi.org/10.2307/30148475. PMid:7683031.
16. Athanazio RA, Silva-Filho LVRF, Vergara AA, Ribeiro AF, Riedi CA Procianoy EFA, et al. Brazilian guidelines for diagnosis and treatment of cystic fibrosis. J Bras Pneumol. 2017;43(3):219-45. http://dx.doi. org/10.1590/s1806-37562017000000065. PMid:28746534.

17. Smyth AR, Bell SC, Bojcin $S$, Bryon $M$, Duff $A$, Flume $P$, et al. European Cystic Fibrosis Society Standards of Care: Best Practice guidelines. J Cyst Fibros. 2014;13(Suppl 1):23-42. http://dx.doi. org/10.1016/j.jcf.2014.03.010. PMid:24856775.

18. Amies CR. A modified formula for the preparation of Stuart's Transport Medium. Can J Public Health. 1967;58(7):296-300. PMid:4859908.

19. Van Pelt C, Verduin CM, Goessens WHF, Vos MC, Tümmler B, Segonds $C$, et al. Identification of Burkholderia spp. in the clinical microbiology laboratory: comparison of conventional and molecular methods. J Clin Microbiol. 1999;37(7):2158-64. PMid:10364579.

20. Doern GV, Brogden-Torres B. Optimum use of selective plated media in primary processing of respiratory tract specimens from patients with cystic fibrosis. J Clin Microbiol. 1992;30(10):2740-2. PMid:1400978.

21. Otto-Karg I, Jandl S, Müller T, Stirzel B, Frosch M, Hebestreit $H$, et al. Validation of Vitek 2 nonfermenting gram-negative cards and Vitek 2 version 4.02 software for identification and antimicrobial susceptibility testing of nonfermenting gram-negative rods from patients with cystic fibrosis. J Clin Microbiol. 2009;47(10):3283-8. http://dx.doi.org/10.1128/JCM.00505-09. PMid:19710272.

22. Marko DC, Saffert RT, Cunningham SA, Hyman J, Walsh J, Arbefeville $S$, et al. Evaluation of the Bruker Biotyper and Vitek MS matrix-assisted laser desorption ionization-time of flight mass spectrometry systems for identification of nonfermenting gramnegative bacilli isolated from cultures from cystic fibrosis patients. J Clin Microbiol. 2012;50(6):2034-9. http://dx.doi.org/10.1128/ JCM.00330-12. PMid:22495566.

23. Alby K, Gilligan PH, Miller MB. Comparison of matrix-assisted lase desorption ionization-time of flight (maldi-tof) mass spectrometry platforms for the identification of gram-negative rods from patients with cystic fibrosis. J Clin Microbiol. 2013;51(11):3852-4. http:// dx.doi.org/10.1128/JCM.01618-13. PMid:23966494.

24. Peckham D, Williams K, Wynne S, Denton M, Pollard K, Barton R Fungal contamination of nebuliser devices used by people with cystic fibrosis. J Cyst Fibros. 2016;15(1):74-7. PMid:26104996.

25. Blyth CC, Harun A, Middleton PG, Sleiman S, Lee O, Sorrell TC et al. Detection of occult scedosporium species in respiratory tract specimens from patients with cystic fibrosis by use of selective media. J Clin Microbiol. 2010;48(1):314-6. http://dx.doi.org/10.1128/ JCM.01470-09. PMid:19906904.

26. Prevaes SMPJ, Winter-de Groot KM, Janssens HM, Piters WAAS, Tramper-Stranders GA, Wyllie $A L$, et al. Development of the nasopharyngeal microbiota in infants with cystic fibrosis. Am J Respir Crit Care Med. 2016;193(5):504-15. http://dx.doi.org/10.1164/ rccm.201509-17590C. PMid:26492486.

27. Saiman L, Siegel JD, LiPuma JJ, Brown RF, Bryson EA, Chambers $\mathrm{MJ}$, et al. Infection prevention and control guideline for cystic fibrosis: 2013 update. Infect Control Hosp Epidemiol. 2014;35(Suppl 1):1-67. http://dx.doi.org/10.1086/676882. PMid:25025126.

28. Saiman L, Siegel J. Infection control in cystic fibrosis. Clin Microbio Rev. 2004:17(1):57-71. http://dx.doi.org/10.1128/CMR.17.1.5771.2004. PMid:14726455.

29. Lester MK, Flume PA, Gray SL, Anderson D, Bowman CM. Nebulizer use and maintenance by cystic fibrosis patients: a survey study. Respir Care. 2004;49(12):1504-8. PMid:15571641. 